Rúbens Prince dos Santos Alves

\title{
Vacinas para o controle da dengue: potencial vacinal da combinação das proteínas não estruturais na geração de resposta celular protetora em modelo experimental
}

Tese apresentada ao Programa de Pós-Graduação em Microbiologia do instituto de Ciências Biomédicas da Universidade de São Paulo, para obtenção do título de Doutor em Ciências. 


\section{Rúbens Prince dos Santos Alves}

\section{Vacinas para o controle da dengue: potencial vacinal da combinação das proteínas não estruturais na geração de resposta celular protetora em modelo experimental}

Tese apresentada ao Programa de Pós-Graduação em Microbiologia do instituto de Ciências Biomédicas da Universidade de São Paulo, para obtenção do título de Doutor em Ciências.

Área de concentração: Microbiologia

Orientador: Prof. Dr. Luís Carlos de Souza Ferreira

Versão original 


\section{RESUMO}

ALVES, R. P. S. Vacinas para o controle da dengue: potencial vacinal da combinação das proteínas não estruturais na geração de resposta celular protetora em modelo experimental [Tese]. São Paulo: Universidade de São Paulo, Instituto de Ciências Biomédicas, 2018. 215 f.

A dengue é uma doença causada por um dos quatro sorotipos do vírus dengue (DENV 1-4), principal arbovírus que atualmente afeta a saúde dos seres humanos. Embora a doença seja conhecida há mais de 70 anos, não existem medicamentos eficazes para o tratamento ou uma formulação mundialmente aceita e capaz de conferir proteção completa contra a infecção. Estudos experimentais e resultados gerados após a liberação da vacina anti-DENV demonstraram que a indução de anticorpos neutralizantes de alto título não representa um correlato de proteção exclusivo e, de fato, respostas imunológicas baseadas em células $T$ desempenham um papel relevante no estabelecimento de imunidade protetora. Nesse contexto, o presente estudo buscou primeiramente demonstrar o papel central das respostas de linfócitos T contra a encefalite induzida por uma cepa de o DENV2 (JHA1) em camundongos imunocompetentes. As respostas protetoras estavam associadas à geração de linfócitos T que reconheciam epítopos das proteínas não estruturais do DENV. Na etapa seguinte, versões recombinantes das proteínas não estruturais 1,3 e 5 administradas em regime vacinal levaram à produção de altos níveis de IFNy que se correlacionou com proteção completa frente ao desafio com a cepa JHA1. A infecção de camundongos C57BL/6 com a cepa JHA1 pela via intravenosa induziu letalidade parcial nesses animais. Baseado neste modelo, constatou-se que os linfócitos T CD8 ${ }^{+}$ funcionais estão associados à proteção no modelo de infeção homotípica primária e secundária pelo DENV. Constatou-se também que os linfócitos $\mathrm{T} \mathrm{CD4}^{+}$gerados durante a infecção pelo DENV3 desempenham papel protetor contra DENV2. Por fim, descrevemos e validamos novos epítopos derivados de proteínas do vírus zika (ZIKV) que reagem de forma cruzada com o DENV2, restritos ao HLA-DBR $1{ }^{*} 0101$, e capazes de induzir imunidade protetora contra o ZIKV quando administrados numa formulação vacinal. Assim, o presente estudo descreveu novos modelos experimentais relevantes para o estudo de DENV e ZIKV, bem como a validação dos mesmos para o desenvolvimento de novas vacinas.

Palavras-chave: Dengue. Vírus da dengue. Vacinas. Modelo animal. 


\begin{abstract}
ALVES, R. P. S. Dengue Vaccine: Potential of Combining Non-structural Proteins in Induce Protective Cell Response in an Experimental Model [Thesis]. São Paulo: Universidade de São Paulo, Instituto de Ciências Biomédicas, 2018. 215 p.

Dengue is a disease caused by one of four dengue virus serotypes (DENV 1-4), which is the main arbovirus currently affecting the health of human beings. Although the disease has been known for over 70 years, there are no effective drugs for treatment or a worldwide aceepted licensed vaccine formulation capable of providing complete protection against infection. Experimental studies and results generated after the release of the anti-DENV vaccine have shown that the induction of high titer neutralizing antibodies does not represent a unique protective correlate and, in fact, T cell-based immune responses play a relevant role in establishing a protective immune state. In this context, the present study first sought to demonstrate the central role of $\mathrm{T}$ lymphocyte responses against encephalitis induced by a DENV2 strain (JHA1) in immunocompetent mice. Protective responses were associated with generation of $\mathrm{T}$ lymphocytes that recognized epitopes of nonstructural DENV proteins. In the next step, recombinant forms of the nonstructural proteins 1,3 and 5 , following delivery in a vaccine regimen, induced the production of high levels of IFNy, which correlated with complete protection against the challenge with DENV2. Intravenous infection of C57BL/6 mice with the JHA1 strain induced partial lethality in these animals. In addition, it was found that functional T CD8 ${ }^{+}$lymphocytes are associated with protection in the model of primary and secondary DENV homotypic infection. $\mathrm{CD}^{+}{ }^{+}$T-lymphocytes generated during DENV3 infection have also been found to play a protective role against DENV2. Finally, we described and validated new zika virus (ZIKV) protein epitopes that cross-react with DENV2, restricted to HLA-DBR1*0101, which were capable of inducing protective immunity against ZIKV when administered in a vaccine formulation. Thus, the present study described new experimental models relevant to the study of DENV and ZIKV, as well as the validation of these models for the evaluation of new vaccines.
\end{abstract}

Keywords: Dengue fever. Dengue virus. Vaccine. Animal model. 